\title{
CD2-Associated Protein
}

National Cancer Institute

\section{Source}

National Cancer Institute. CD2-Associated Protein. NCI Thesaurus. Code C97249.

CD2-associated protein (639 aa, $71 \mathrm{kDa}$ ) is encoded by the human CD2AP gene. This protein plays a role in both cell division and protein-protein binding. 